\title{
New centre is launched
}

\section{Heidelberg}

DespiTe an attempt to burn it down before it was occupied, and still under makeshift leadership, the Centre for Molecular Biology of the University of Heidelberg (ZMBH) has begun to fill up and is heading confidently for its official inauguration in November.

$\mathrm{ZMBH}$ has its origins in the decision of the German chemical company Hoechst in 1982 to invest US\$50 million into a new department of molecular biology at Massachusetts General Hospital in Boston. Stunned by both the sum of money and its export to the United States, University of Heidelberg molecular biologists persuaded BASF, best known for cassette tapes, to provide the seed money for ZMBH. The state of Baden Württemberg then chipped in with a building and salaries for 30 technical and administrative staff and the federal ministry of science and technology (BMFT) provided financial support to $\mathrm{ZMBH}$ as the first of four national gene centres.

Built in the shadow of the German Cancer Research Centre, which has about 60 per cent of its 1,200 staff in permanent posts, $\mathrm{ZMBH}$ with 200 staff will give tenure only to eight or so senior scientists, not all of whom have yet been recruited. Though full professors of the university, their teaching load will be a quarter of the standard eight hours a week, which is possible because ZMBH has the status of a central institute of the university, like the botantical garden. They will, nonetheless, take both graduate and postgraduate students.

Research funds will come from three core grants, the biggest one of which has been approved in principle by BMFT and will be worth at least DM6 million for each of the next four years. The other two grants are in the form of Sonderforschungsbereich support from the German Research Society (DFG). One grant, for neuroscience, has been approved. The other, for gene expression, is expected to be approved soon following a site visit two weeks ago.

BASF's contribution of an annual DM1 million for ten years seems in part to be slush money. It is likely, for example, to help provide a sufficient salary to lure to ZMBH a senior German scientist in a leading US biotechnology company. In retum for their support, BASF gains only the right to attach two of its researchers to ZMBH. Merck (of Darmstadt), who have recently agreed to provide a smaller sum of money, will be allowed one attached scientist in return.

Despite various ambitions, there is no director of $\mathrm{ZMBH}$ and it is not clear if one will emerge. Initial attempts to sort the matter out were confounded by possible conflicts of interest when some of the candidates founded a biotechnology company (there is now a rule that industrial involvement is acceptable as long as it does not include membership of an executive board). At present there is a directorate of five senior staff with Professor Heinz Schaller as their elected "speaker". But with the imminent arrival of Hermann Bujard, one of the initiators of $\mathrm{ZMBH}$ and presently at Hoffman-LaRoche in Basle, it seems likely that the directorate will be slimmed down and that Bujard, or perhaps Schaller, will head it.

Above the directorate is the rector of the university who is assisted by a scientific advisory board. The board, which is international, advises on senior appointments and the scientific programme of ZMBH

As long as there is no repeat of the bungled attempt to burn down the building - a fuse foiled the unknown arsonists, who seem to have been driven by a gene phobia - ZMBH should be a good showplace for the University of Heidelberg as it celebrates its 500 th anniversary next year.

Peter Newmark

\section{China chases share in Eureka}

\section{Beijing}

The People's Republic of China seems anxious to play some part in Eureka, the French inspired programme of collaborative research and development in high technology. So much became clear at the end of last week, during meetings between a French delegation led by $\mathrm{M}$. Hubert $\mathrm{Cu}$ rien, the minister of research in Paris, and officials of the Chinese government.

Members of the French delegation said they had been surprised at the way in which the Chinese side had brought up the issue of participation early in the talks, which among other things covered collaboration in biotechnology. Precisely how China might play a part in Eureka was by no means clear but in circumstances in which the French enthusiasm has not been matched by that of other European governments, the chances are that some way will be found.

Meanwhile, Chinese researchers are intrigued that one of them, Professor Guang Zhao, was promoted to become a member of the Central Committee of the Chinese communist party at last week's national meeting, that at which veteran members of several party organs were replaced by somewhat younger people.

Professor Zhao, once head of the Beijing Institute of Theoretical Physics, is 56, and is believed to be the intended successor of Professor Lu Xiang, now president of the Chinese Academy of Science.

John Maddox
Rural India Longer life for
thatched roof

New Delhi

INDIAN scientists engaged in improving the lot of the rural poor have found a simple, cheap and effective method for extending the life of the perishable coconut leaf thatch and making it fireproof. Coconut leaf (with a world production of 42 million tonnes) is a major roofing material in the tropics, and in India alone some 38 million houses are thatched. as well as thousands of cinemas and schools. The thatched roofs normally need replacement every year, but their life span has now been extended to four years by treating the thatch with chemicals that are neither washed away by rain nor degraded in sunlight.

"The use of treated thatch will lead to enormous savings in materials and labour", says Dr C.K.S. Pillai, a polymer chemist at the Regional Research Laboratory (RRL) in Trivandrum, in the state of Kerala. During a five-year research project, Pillai and his team found that coconut leaves deteriorate due to rain, alternate wet-and-dry cycles and more importantly due to attack by fungi entering through the stomatal openings of the leaves. Five types of fungi were isolated from decayed thatch and were subsequently identified by the Commonwealth Mycological Institute in London. So Pillai attacked the problem by coating the thatch with a combination of fungicide and a water repellent.

In the process recommended by RRL. copper sulphate is used as a fungicide because it is cheap. The chemical is dissolved in water and sprayed on both sides of the thatch, or the thatch is dipped in copper sulphate solution and dried. The dried thatch is then sprayed on both sides with a liquid extracted from the shell of cashew nuts (CNSL) and mixed with kerosene. CNSL, a by-product of the cashew nut industry, is an excellent water repellent besides being cheap. Trials conducted by Pillai have shown that roofs made of treated thatch survive for four years while untreated roofs, under similar conditions, collapse in 12 months.

Chemically treated thatches are now being used on a large scale in Mitraniketan village in Kerala, and other villages are catching up with this new technology.

Although the copper sulphate/CNSL combination extends roof life, it does not provide immunity to fire. To make the thatch fireproof, the RRL team converted CNSL into its phosphorylated derivative - an excellent fire retardant - by heating CNSL with phosphoric acid. A coating of copper sulphate followed by spraying of phosphorylated-CNSL is recommended by RRL to give added life to thatch as well as to protect it from fire. 
Attempts to extend the life of coconut leaf thatch have been going on for over a decade in several laboratories across the world. At least nine methods have emerged for extending thatch life and 12 chemical treatments have been suggested for making it fireproof. Pillai says the chemicals used so far are either costly or a health hazard or leached by rain. The RRL recipe is claimed to be cheap, safe and nonleachable.

As well as India, the RRL process may benefit Sri Lanka and the Polynesian islands where coconut leaf is the main roofing material in rural homes. Longer life for thatched roofs would result in surplus coconut leaves which, according to RRL, could be used to make newer products. Pillai and his team have already made brown paper from the pulp of the leaves. and laminated products such as table tops and door panels directly from the leaves. "The laminates are made by plaiting the leaflets into sheets and using these sheets as plys as in the case of plywood", says Pillai.

K.S. Jayaraman

\section{US biological weapons \\ Protests over US Army lab}

Washington

THE latest attempts by lobbying groups to persuade Congress to regulate the military use of biological research has centred on the US Army's "aerosol test facility" at Dugway. Utah.

Fourteen groups, coordinated by the Committee for Responsible Genetics, are seeking a ban on all classified research and development "aimed at producing new or altered biological agents with properties useful for biological and chemical warfare". They also want an investigation into allegations that the Soviet Union and its allies are developing biological weapons, incorporation of the 1972 Biological Weapons Convention into US domestic law and a complete halt to the proposed aerosol testing facility.

Congress has approved a $\$ 300$ million modernization of the Dugway Proving Ground, the Army's primary test site for biological and chemical research. However, the controversial part of the project is the proposed special testing laboratory for handling "toxic biological aerosol agents", and construction of the laboratory has been delayed by a court injunction which will remain in force until the Army produces an "adequate" environmental assessment.

The Army has responded by stating that it will prepare an "environmental impact statement", a much more detailed study than required by law, and will contract out the work to an independent organization in an attempt to avoid suggestions of bias. An Army spokesman stressed that the

Acid rain

\section{Upwind versus downwind}

Less affected countries relegate acid rain issues to faraway forests: those more affected have so far failed to implement a policy designed to handle the chemical complexity and long-term effects of acid pollution. By drawing together worldwide data on the problem. a report published this week by the environmental pressure group Earthscan tries to bring the problem closer to home. It argues that acid pollution is rapidly spreading to the Third World, that downwind countries will place increasing pressure on upwind pollution sources, and that buildings and crops are as much damaged as trees and fish.

These data, according to the report. widen the scope of acid pollution. Not all acid deposition is wet. for example; onethird of sulphur emissions in the northeastern United States is thought to be dry deposited. converted to acid on the surfaces of plants and buildings. Not all acid deposition is sulphur dioxide from fuelburning plants; nitrogen oxide and ozone are among the culprits, and cars and fertilizers as much a problem as smoke stacks. Among the less industrialized countries, China faces the greatest risks, especially from inefficient combustion of low-quality coals; and Brazil, says the report, is one of the most polluted countries on Earth.

"Downwind countries like Norway, Sweden, Canada and Germany are simply not prepared to have their environment destroyed from abroad. There is already serious talk in Sweden of taking Britain to the International Court and in Norway of offering loans to Britain and Poland to finance anti-pollution measures at our power stations", says Jon Tinker, director of Earthscan.

The effects of acid pollution on trees and lakes have excited the most research, but the tangle of cause and effect has led to disagreement about the impact on the en-

Dugway programme is "entirely defensive in orientation" and that there is no development of "delivery mechanisms" for biological agents planned anywhere in the Army's research programme.

Environmental and other organizations, however, fear that military biological research signals a "new spiral in the arms race". The validity of "defensive" biological research is questioned.

"Given the enormous natural variety of potentially infectious agents, together with the extraordinarily increased variation and novelty that genetic engineering technology provides, it is not possible to protect a population against biological warfare" Dr Jonathan King, professor of molecular biology at the Massachusetts Institute of Technology, told congressional representatives. And Dr Francis Boyle, professor of law at the University of Illinois, challenged the "Reagan administra- vironment of such pollution. Last week. for example. Dr David Lonsdale. the plant pathologist of the Forestry Commission, claimed that the damage to Britain's beech woods was not caused by acid pollution. Resort areas dependent on their trees, however, such as West Germany's Black Forest, claim that there is enough evidence to justify governmental action.

The damage goes deeper than leaves on trees, according to the Earthscan report. As chemicals wash through the ground. the soil becomes more acidic. Soil under ice during the last Ice Age, including those in South America. Africa and southern Asia, are young in age and have less buffering capacity. Aluminium is a key prob-

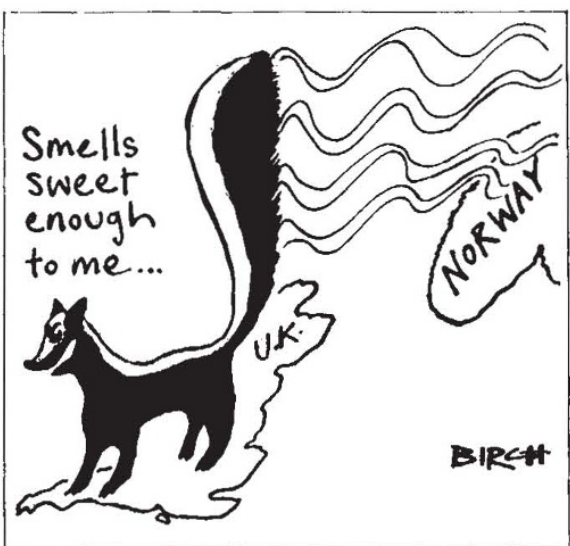

lem. Normally tied to soil particles, chemical combination frees aluminium to damage root filaments and enter freshwater, where it has proven toxic throughout food chains. Lakes can be limed, but there are no data on how to treat soils, nor on how long they take to recover.

Elizabeth Collins

Acid Earth, by John McCormick, is published by International Institute for Environment and Development, London, and costs £3.95/\$6.25.

tion's ... claims that the Soviets cannot be trusted with respect to the conclusion of future chemical and biological arms control agreements".

Dr Boyle argued that, in the absence of evidence for violations of biological weapons agreements, there is no need to support "recombinant DNA biological warfare research in the USA", although he recommended that Congress should "continue to monitor" the situation, as well as improving existing treaty arrangements.

Although the Army says that most of its evidence for Soviet involvement in biological warfare research comes from intelligence sources, one much-quoted example is the possible use of mycotoxins in "yellow rain" in South-East Asia. The Army refused to confirm or deny that mycotoxins would be used at Dugway.

Maxine Clarke 